
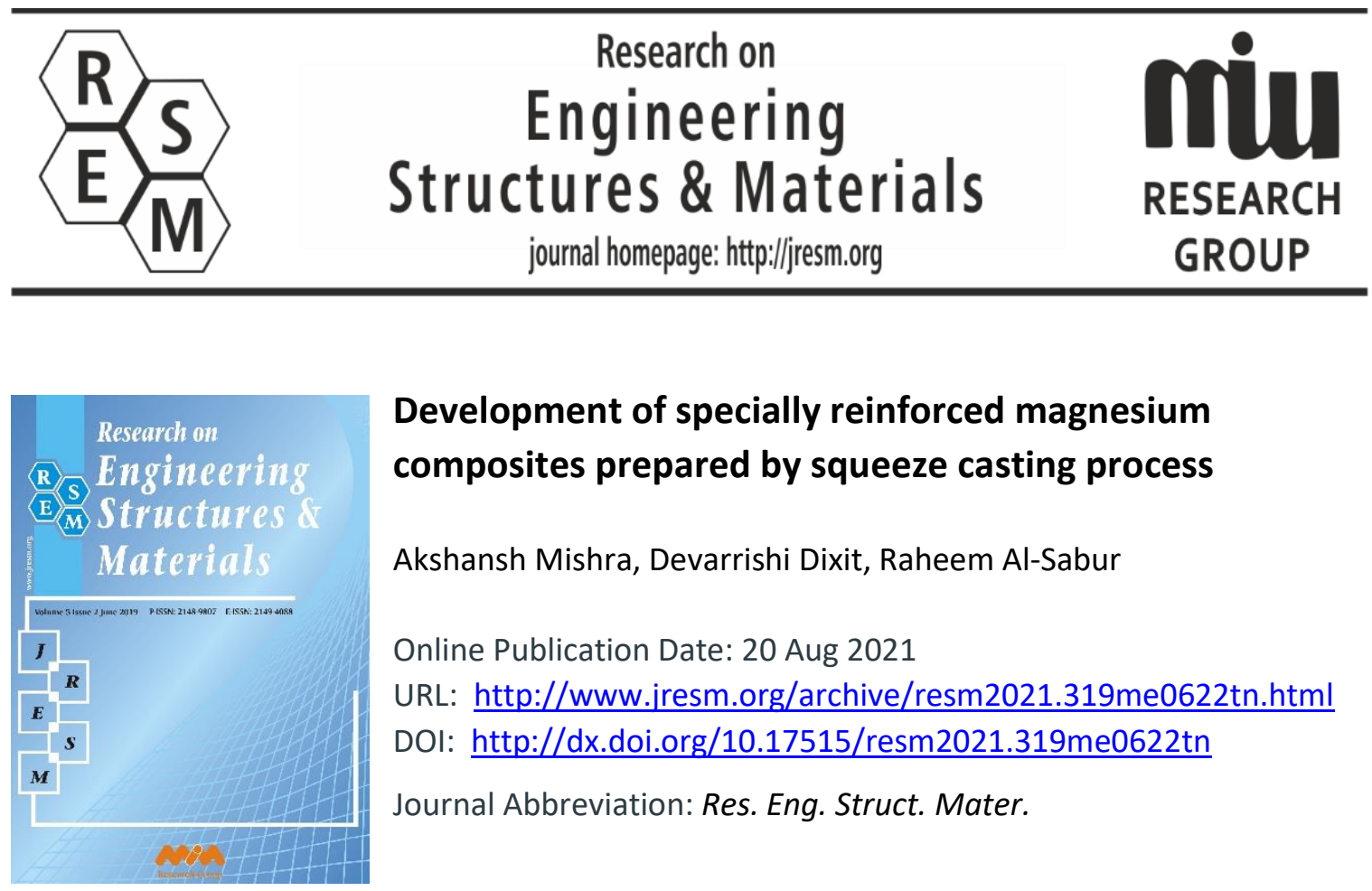

\title{
Development of specially reinforced magnesium composites prepared by squeeze casting process
}

Akshansh Mishra, Devarrishi Dixit, Raheem Al-Sabur

Online Publication Date: 20 Aug 2021

URL: http://www.jresm.org/archive/resm2021.319me0622tn.html

DOI: http://dx.doi.org/10.17515/resm2021.319me0622tn

Journal Abbreviation: Res. Eng. Struct. Mater.

\section{To cite this article}

Misha A, Dixit D, Al-Sabur R. Development of specially reinforced magnesium composites prepared by squeeze casting process. Res. Eng. Struct. Mater., 2021; 7(4): 635-646.

\section{Disclaimer}

All the opinions and statements expressed in the papers are on the responsibility of author(s) and are not to be regarded as those of the journal of Research on Engineering Structures and Materials (RESM) organization or related parties. The publishers make no warranty, explicit or implied, or make any representation with respect to the contents of any article will be complete or accurate or up to date. The accuracy of any instructions, equations, or other information should be independently verified. The publisher and related parties shall not be liable for any loss, actions, claims, proceedings, demand or costs or damages whatsoever or howsoever caused arising directly or indirectly in connection with use of the information given in the journal or related means.

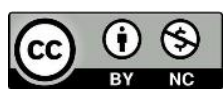
Published articles are freely available to users under the terms of Creative Commons Attribution - NonCommercial 4.0 International Public License, as currently displayed at here (the "CC BY - NC"). 


\title{
Research on Engineering Structures \& Materials
}

journal homepage: http://jresm.org

Technical Note

\section{Development of specially reinforced magnesium composites prepared by squeeze casting process}

\author{
Akshansh Mishra ${ }^{* 1, a}$, Devarrishi Dixit ${ }^{2, b}$, Raheem Al-Sabur ${ }^{3, c}$ \\ ${ }^{1}$ Centre for Artificial Intelligent Manufacturing Systems, Stir Research Technologies, India. \\ ${ }^{2}$ Department of Material Science, Christian-Albrechts-Universität zu Kiel \\ ${ }^{3}$ Department of Mechanical Engineering, University of Basrah, Basra 61001, Iraq
}

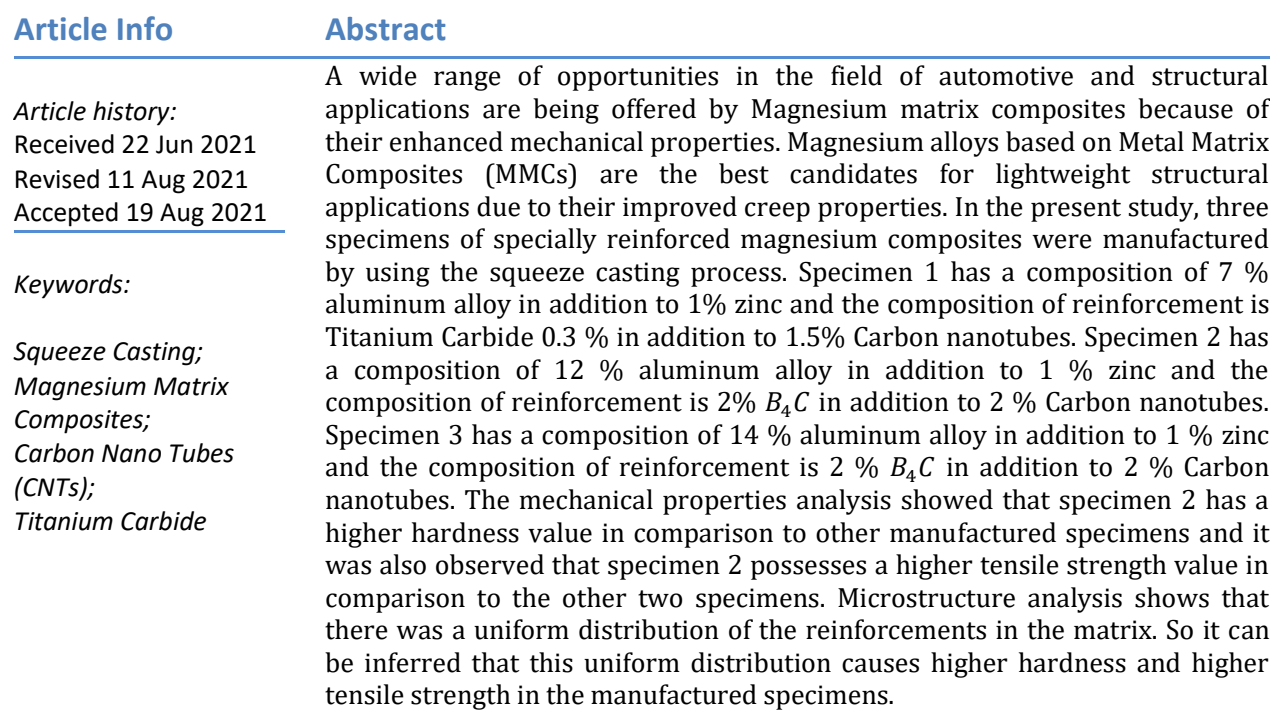

(C) 2021 MIM Research Group. All rights reserved.

\section{Introduction}

Metal Matrix Composites (MMCs) can be considered lightweight structural materials that were developed in the 1990s for meeting the requirements in aerospace applications [1$3]$. They have a strong potential to replace cast iron and other materials in brakes and engines due to their high strength-to-weight ratio, low density, high fatigue, wear and creep resistance, and at last high-temperature strength retention [4-5]. Magnesium and its alloys have attracted much attention in scientific development and as well as in various commercial applications because of their low density and high specific strength in comparison to other structural metals. In aerospace and automotive applications these properties order to reduce weight, greenhouse emission, and fuel consumption [6-8]. But due to their poor creep resistance behavior at high temperatures, the application of magnesium and its alloys are limited. So to overcome these limitations and to improve the properties, reinforcements are incorporated [9-10]. Dinaharan et al. [11] reinforced titanium particles $(0,7,14$, and $21 \mathrm{vol} \%)$ into an AZ31 magnesium alloy by friction stir processing method. The obtained results showed enhanced tensile strength and good ductility in the manufactured composite. Say et al. [12] investigated the corrosion resistance and mechanical properties of AZ91 and AZ61 magnesium matrix composites

\footnotetext{
*Corresponding author: akshansh@stirresearchtech.in

a orcid.org/0000-0003-4939-359X; b orcid.org/0000-0002-5126-6154; c orcid.org/0000-0003-1012-7681 DOI: http://dx.doi.org/10.17515/resm2021.319me0622tn
}

Res. Eng. Struct. Mat. Vol. 7 Iss. 4 (2021) 635-646 
reinforced with $01,0.2$, and $0.5 \mathrm{wt} \%$ carbon nanotubes (CNTs). It was observed that with the increasing amount of carbon nanotubes, the strength of composites increases. Chang et al. [13] used squeeze casting process for manufacturing high-strength and high-

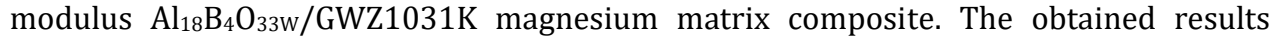
showed that the Yield Strength (YS), Ultimate Tensile Strength (UTS) and Young's modulus of the material at room temperature resulted $364 \pm 13 \mathrm{MPa}, 380 \pm 16 \mathrm{MPa}$ and $77.8 \pm 2.1 \mathrm{GPa}$. Kumar et al. [14] implemented squeeze casting process for fabricating high-performance aluminum composite material where agro waste reinforcements were used. The results showed that the manufactured composite material has high strength and toughness. Kale et al. [15] studied the tribological and mechanical properties of A7075/ SiC/ B4C hybrid composite which is manufactured by squeeze casting process. The results showed that the fabricated composite has more tensile and compressive strength in comparison to base metal alloy.

In recent work, the squeeze casting process has been used for fabricating the magnesiumbased Metal Matrix Composites (MMCs). In the next sections, the experimental procedure and results obtained will be further discussed.

\section{Material and Methods}

Firstly, the ingots of magnesium, aluminum, and zinc weighing in the range of 950 to 990 grams per specimen were taken for composing the matrix purpose. Secondly, the preheating of the ingot mixture consisting of magnesium, aluminum, and zinc is carried out to a temperature of 650 degrees celsius. Thirdly, carbon nanotubes powder with $B_{4} \mathrm{C}$ powder are added as reinforcements then the mixture is taken into an oven and is preheated to a temperature of 300 degrees celsius. After that, by using a funnel these mixtures are poured into a furnace where the mixture is subjected to a stirring process to enhance the homogenous nature in the mixture at a different rotation rate for 10 minutes. The furnace gate is then opened after the stirring process and through the runner molten composite is further transferred to squeeze die arrangement. At a pressure of 40.2 tonnes, compression is performed by the hydraulic press on the obtained composite inside the die. The cooling process is incurred on the composite for 10 minutes inside the die. After cooling, the fabricated composite is taken outside for carrying out the finishing and machining process. Figure 1 shows the specimen after casting and Figure 2 shows the specimen after finishing the operation. Table 1 shows the composition of fabricated specimens.

Table 1. Composition of composite specimens in weight $\%$

\begin{tabular}{cccccc}
\hline $\begin{array}{c}\text { Specimen } \\
\text { Number }\end{array}$ & $\mathrm{Al}$ & $\mathrm{Zn}$ & $\mathrm{TiC}$ & $B_{4} C$ & $\begin{array}{c}\text { Carbon } \\
\text { Nanotubes }\end{array}$ \\
\hline 1 & 7 & 1 & 0.3 & - & 1.5 \\
2 & 12 & 1 & - & 2 & 2 \\
3 & 14 & 1 & - & 2 & 2 \\
\hline
\end{tabular}




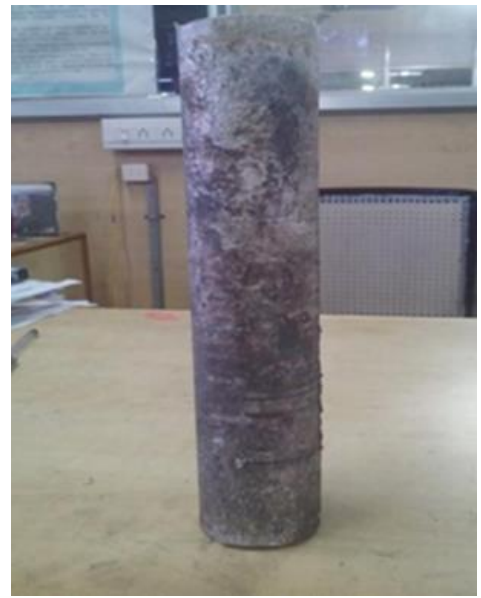

Fig. 1 Specimen obtained after casting process

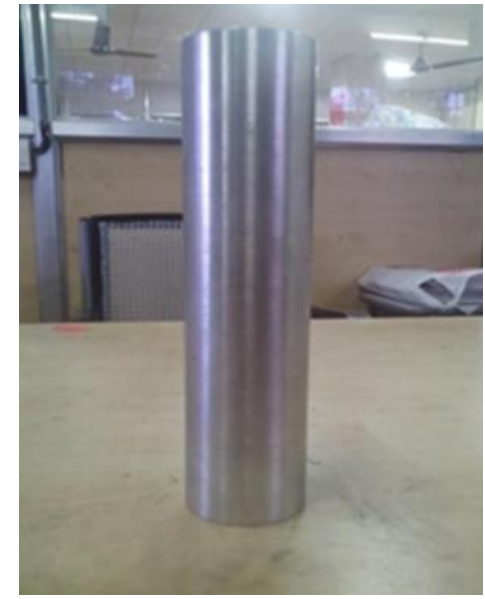

Fig. 2 Specimen obtained after finishing operation

\section{Results and Discussion}

\subsection{Microstructure Properties Analysis}

For obtaining the clear grain boundaries in the microstructure a proper specimen preparation is needed. Polishing and etching are the two kinds of preparation that are subjected to these specimens as shown in Figure 3 and Figure 4.

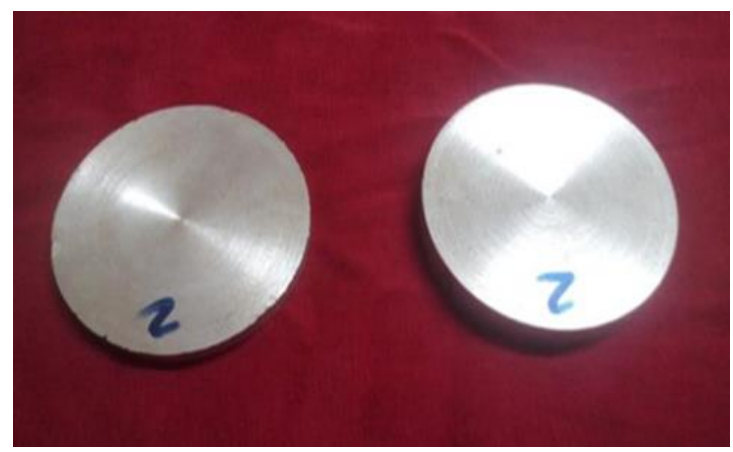

Fig. 3 Non-etched and unpolished composite specimen

The specimen surfaces may appear smooth to the human eyes but in reality, it consists of various scratches, irregularities, and grooves that happen when the specimen is subjected to various machining operations. So to increase the surface smoothness of the surface, polishing is done with different grades of emery paper such as $800,1000,1200$, and 1500. For clear grain boundary observation, the etchant consisted of $92 \mathrm{ml}$ distilled water, $6 \mathrm{ml}$ of nitric acid with $65 \%$ concentration, and $2 \mathrm{ml}$ of hydrofluoric acid with 40 $\%$ concentration. The microstructures obtained for specimen 1, specimen 2, and specimen 3 are shown in Figures 5-7. 


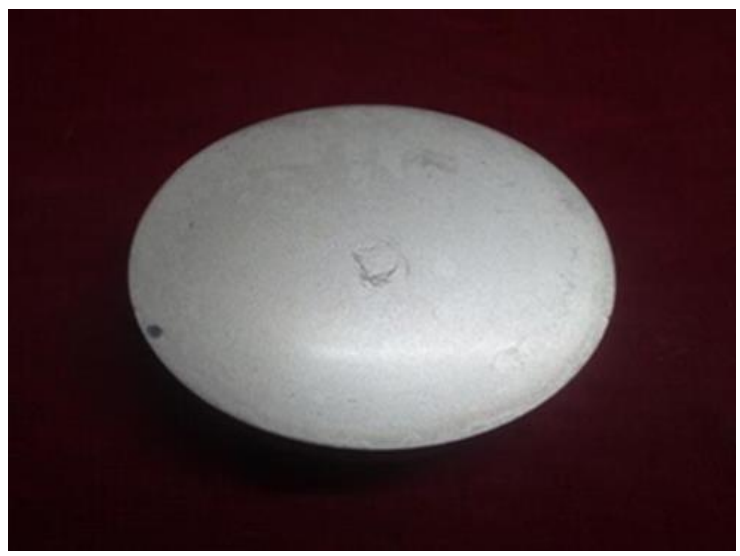

Fig. 4 Etched and emery polished surface of composite specimen

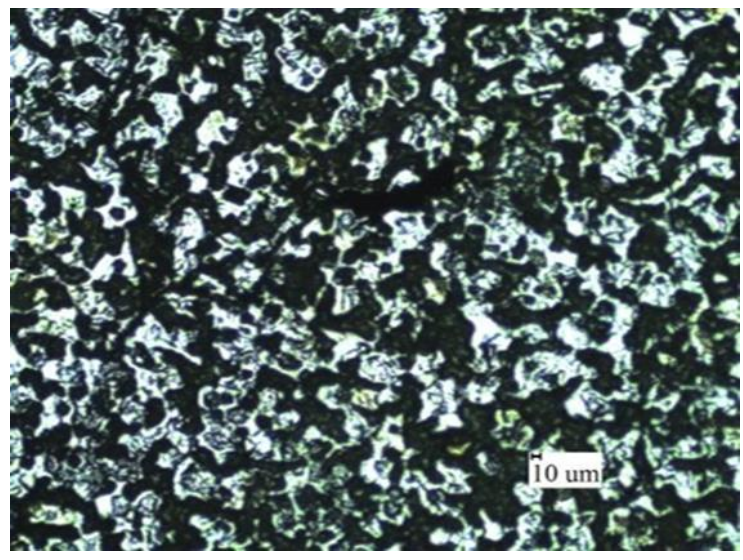

Fig. 5 Microstructure of specimen 1 at the magnification of $100 \mathrm{X}$.

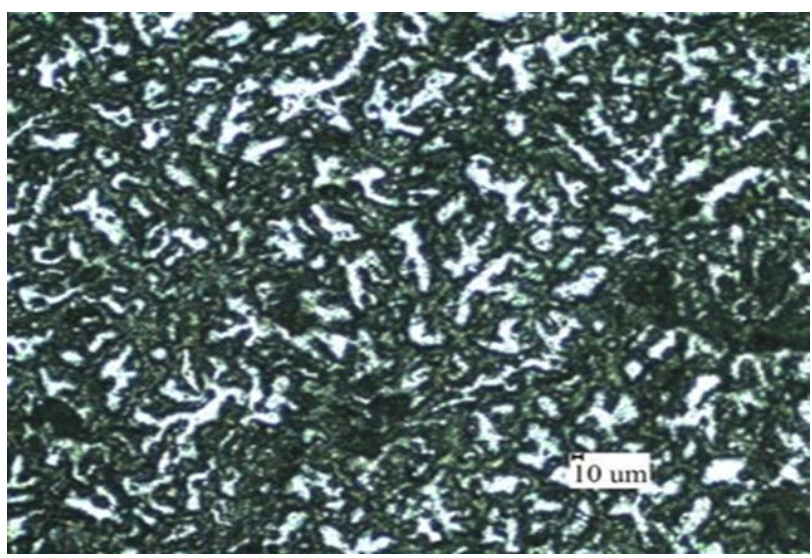

Fig. 6 Microstructure of specimen 2 at the magnification of $100 \mathrm{X}$ 


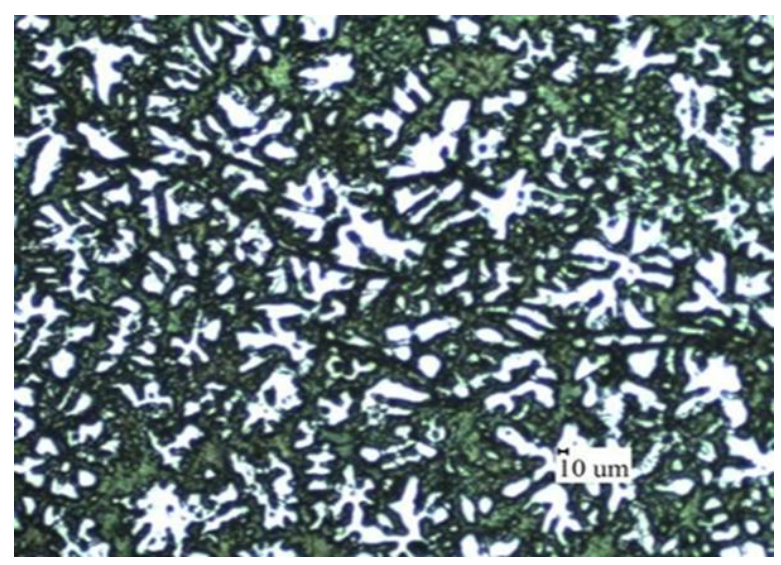

Fig. 7 Microstructure of specimen 3 at the magnification of $100 \mathrm{X}$

From the microstructure analysis of specimen 1, it is observed that there was a nonuniform distribution of the reinforcement in the matrix. It is also observed that due to the existence of slipping between grain boundaries there is a formation of extremely coarse microstructure. From the microstructure analysis of specimen 2, it is observed that there is a uniform distribution of the reinforcement in the matrix and also might be due to less slip occurrence the formation of the microstructure is very fine in comparison to the other two specimens. From the microstructure analysis of specimen 3, it is observed that the reinforcement distribution is slightly non-uniform in nature and it was also observed that in comparison to specimen 1 the microstructure obtained was fine but in comparison to specimen 2 the grain boundaries obtained are coarse due to occurrence of slipping between the grain boundaries. The microstructures obtained from the SEM test for these three specimens are shown in Figures 8-10.

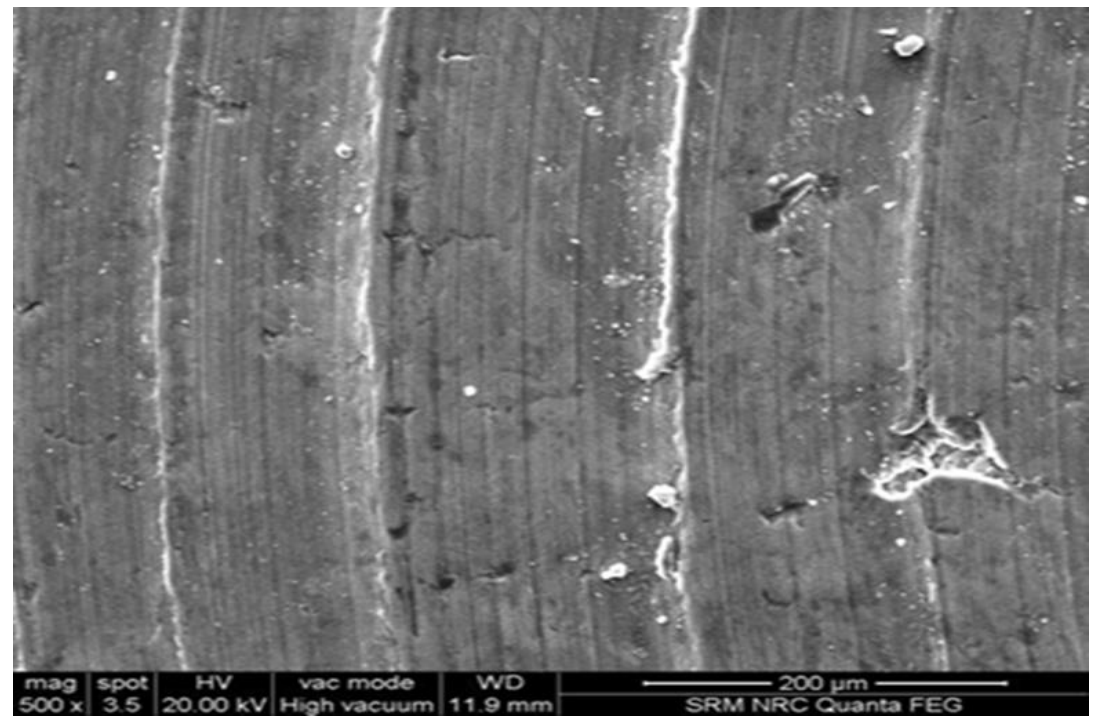

Fig. 8 SEM microstructure of Specimen 1 


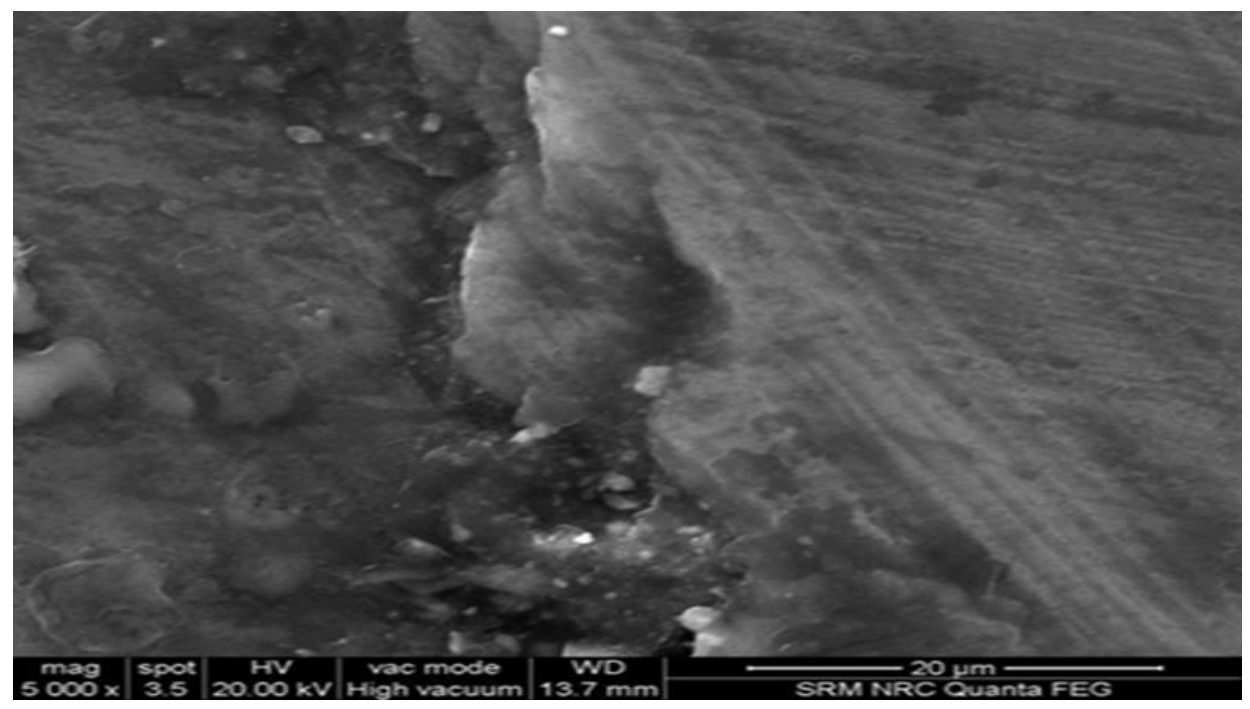

Fig. 9 SEM microstructure of Specimen 2

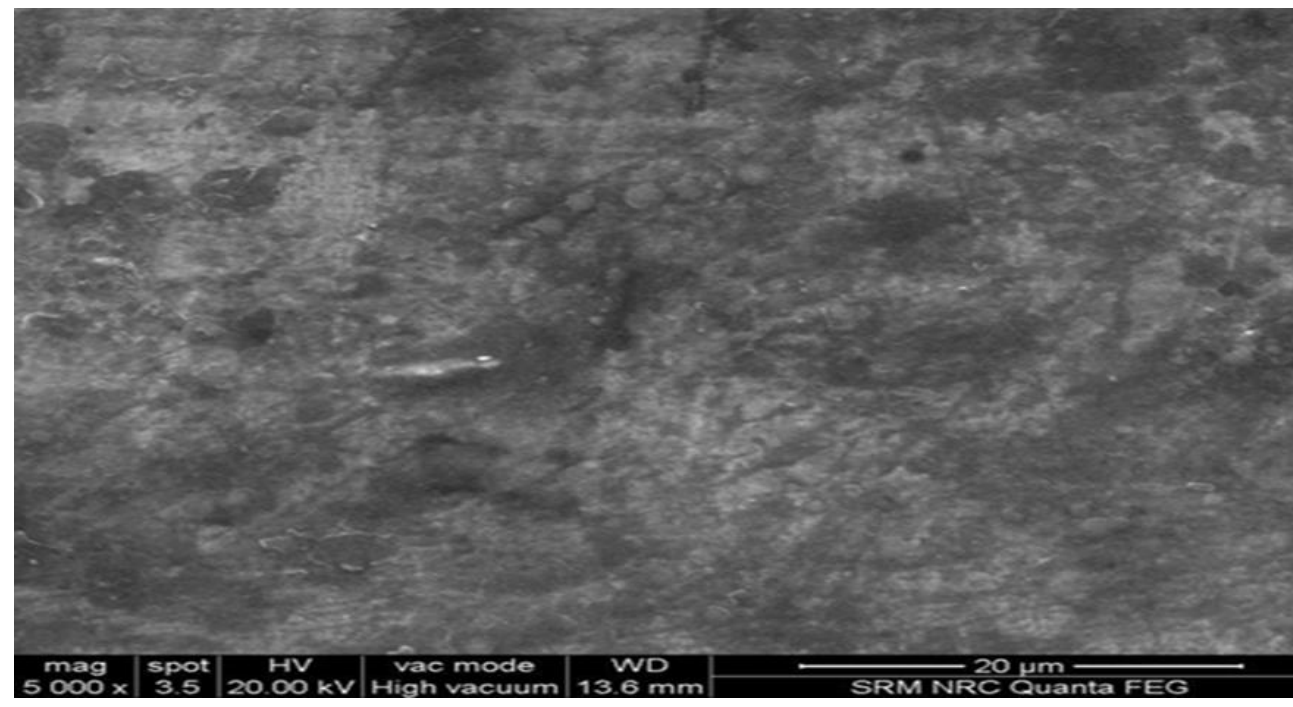

Fig. 10 SEM microstructure of specimen 3

\subsection{Mechanical Properties Analysis}

Tensile test results for specimen 1, specimen 2 and specimen 3 are shown in Figures 1113 and Tables 2-4. 


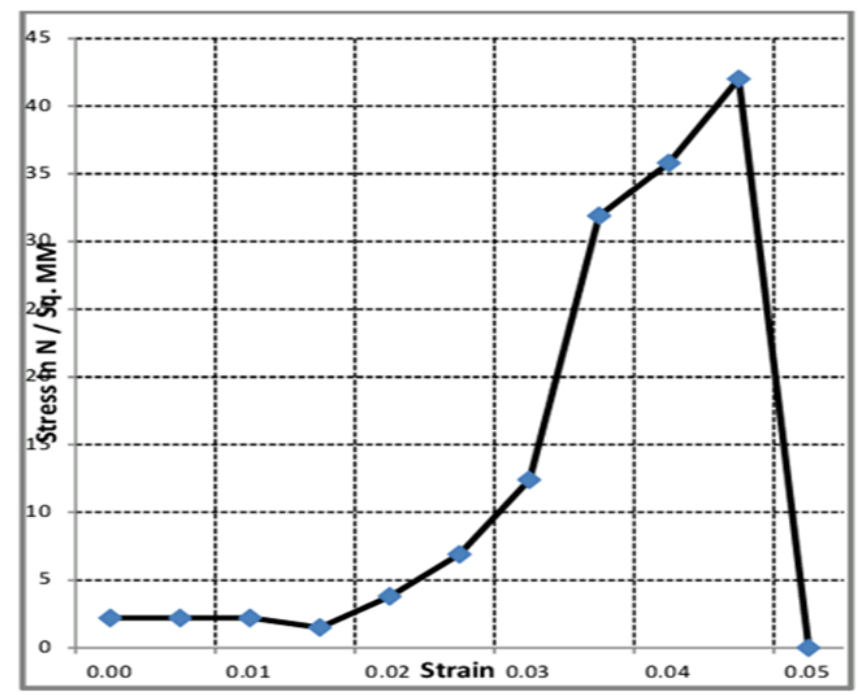

Fig. 11 Tensile test graph plot of specimen 1

Table 2. Tensile Test results of specimen1

\begin{tabular}{cc}
\hline & Specimen 1 \\
Part & Tensile MG 01 \\
Material & MG01 GR \\
Test Mode & Peak/Break \\
High Limit & $20000 \mathrm{~N}$ \\
Low Limit & $10 \mathrm{~N}$ \\
Cross Section Area & $12.56 \mathrm{square} \mathrm{mm}$ \\
Sample Length & $20.0 \mathrm{~mm}$ \\
Selected Load Cell & $20 \mathrm{kN}$ \\
Test Speed & $5.0 \mathrm{~mm} / \mathrm{min}$ \\
Peak Load & $528 \mathrm{~N}$ at length: $0.9 \mathrm{~mm}$ \\
Break Load & $450 \mathrm{~N}$ at length: $1.0 \mathrm{~mm}$ \\
Peak Displacement & $4.5 \%$ \\
Break Displacement & $5.0 \%$ \\
Tensile/Compressive Stress & $42.0 \mathrm{~N} / \mathrm{sq} . \mathrm{mm}$ \\
Ultimate Tensile Strength & $42.0 \mathrm{~N} / \mathrm{sq} . \mathrm{mm}$ \\
\hline
\end{tabular}




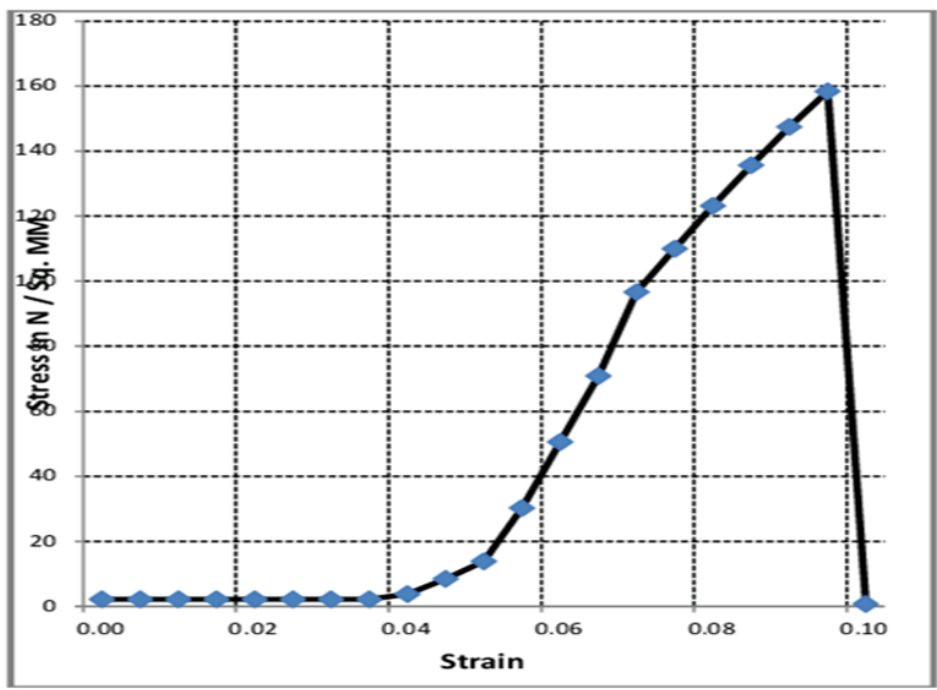

Fig. 12 Tensile test graph plot of specimen 2

Table 3. Tensile Test results of the specimen 2

\begin{tabular}{cc}
\hline & Specimen 2 \\
Part & Tensile MG02 \\
Material & MG02 GR \\
Test Mode & Peak/Break \\
High Limit & $20000 \mathrm{~N}$ \\
Low Limit & $10 \mathrm{~N}$ \\
Cross Section Area & $12.56 \mathrm{sq} . \mathrm{mm}$ \\
Sample Length & $20.0 \mathrm{~mm}$ \\
Selected Load Cell & $20 \mathrm{KN}$ \\
Test Speed & $5.0 \mathrm{~mm} / \mathrm{min}$ \\
Peak Load & $1990 \mathrm{~N}$ at length: $1.9 \mathrm{~mm}$ \\
Break Load & $1990 \mathrm{~N}$ at length: $1.9 \mathrm{~mm}$ \\
Peak Displacement & $9.5 \%$ \\
Break Displacement & $9.5 \%$ \\
Tensile/Compressive Stress & $158.4 \mathrm{~N} / \mathrm{sq} . \mathrm{mm}$ \\
Ultimate Tensile Strength & $158.4 \mathrm{~N} / \mathrm{sq} . \mathrm{mm}$ \\
\hline
\end{tabular}




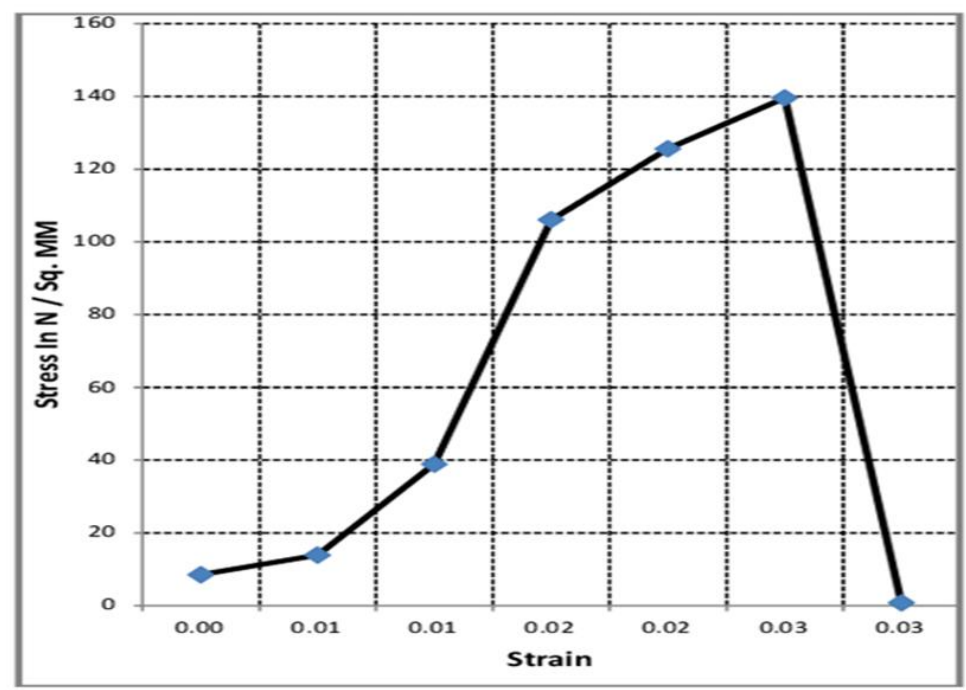

Fig. 13 Tensile test graph plot of specimen 3

Table 4. Tensile Test results of the specimen 3

\begin{tabular}{cc}
\hline & Specimen 3 \\
\hline Part & Tensile MG03 \\
Material & MG03 GR \\
Test Mode & Peak/Break \\
High Limit & $20000 \mathrm{~N}$ \\
Low Limit & $10 \mathrm{~N}$ \\
Cross Section Area & $12.56 \mathrm{sq} . \mathrm{mm}$ \\
Sample Length & $20.0 \mathrm{~mm}$ \\
Selected Load Cell & $20 \mathrm{KN}$ \\
Test Speed & $5.0 \mathrm{~mm} / \mathrm{min}$ \\
Peak Load & 1754 at length: $0.9 \mathrm{~mm}$ \\
Break Load & 1754 at length: $1.0 \mathrm{~mm}$ \\
Peak Displacement & $2.5 \%$ \\
Break Displacement & $2.5 \%$ \\
Tensile/Compressive Stress & $139.6 \mathrm{~N} / \mathrm{sq} . \mathrm{mm}$ \\
Ultimate Tensile Strength & $139.6 \mathrm{~N} / \mathrm{sq} . \mathrm{mm}$ \\
\hline
\end{tabular}

From Figure 11 it is observed that the Ultimate Tensile Strength (UTS) of specimen 1 is very less in comparison to the other two specimens. It is also observed that there is a difference between the breaking load and peak load which indicates that specimen 1 has undergone slight yielding as shown in Figure 14 when tensile force was acting on the specimen. 


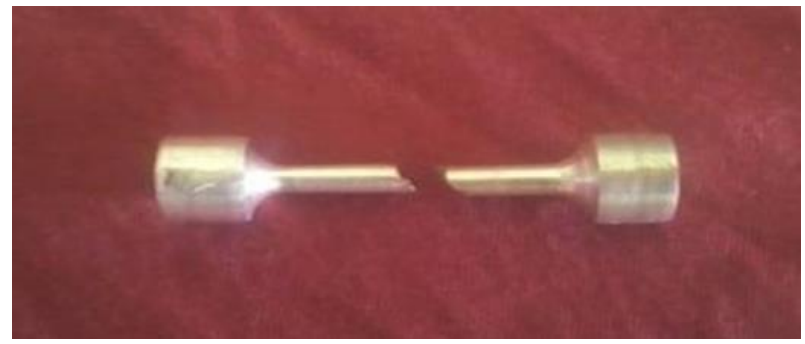

Fig. 14 Fractured specimen 1

From Figure 12 it is observed that the Ultimate Tensile Strength of specimen 2 is higher than specimen 1 . It is also observed that both breaking load and peak load are equivalent which means that specimen 2 has not undergone a yielding effect concluding that specimen 2 is brittle as shown in Figure 15.

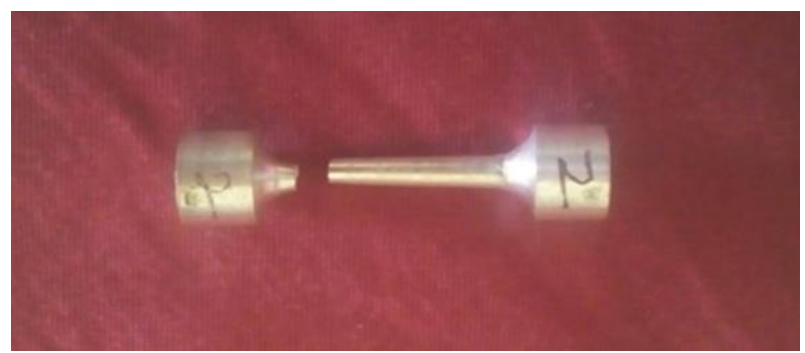

Fig. 15 Fractured specimen 2

From Figure 13 it is observed that in comparison to specimen 1, specimen 3 has a higher value of Ultimate Tensile Strength due to the presence of higher aluminum content in specimen 3. It is also seen that the breaking load and peak load are equivalent which results in a non-yielding process leading to the presence of brittle behavior in specimen 3 as shown in Figure 16.

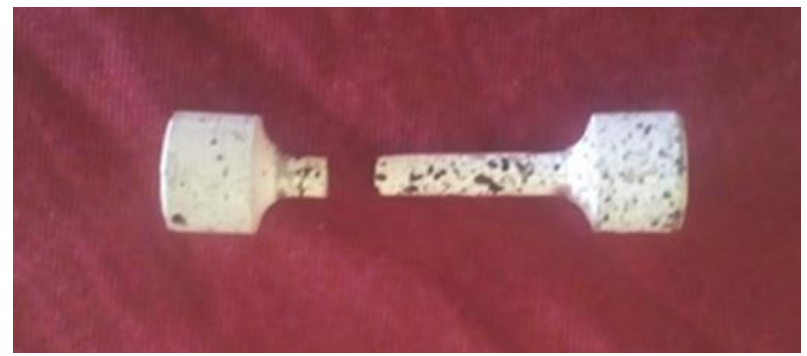

Fig. 16 Fractured specimen 3

For the Micro Vickers hardness test, the apparatus was adjusted to apply $100 \mathrm{~g}$ force on all three specimens. The obtained results are shown in Table 5. At the position of the formation of defects such as micro holes, the hardness value will be less. It can be observed from the result that specimen 2 has a higher value in comparison to the other two specimens. 
Table 5. Micro Vickers Hardness test results

\begin{tabular}{cccc}
\hline $\begin{array}{c}\text { Vickers Hardness } \\
\text { Value }\end{array}$ & Specimen 1 & Specimen 2 & Specimen 3 \\
\hline Reading 1 & 57.4 & 77.7 & 51.8 \\
Reading 2 & 38.7 & 87.4 & 53.5 \\
Reading 3 & 58.2 & 53.3 & 56.5 \\
Mean Value & 51.4 & 72.8 & 53.9 \\
\hline
\end{tabular}

\section{Conclusions}

In the present research work, three specially reinforced magnesium composites specimen were prepared by using the squeeze casting process Due to the incorporation of different reinforcements in the magnesium matrix, novel magnesium matrix composites have been manufactured. Specimen 2 has fewer external and internal defects so its Micro Vickers hardness value is greater than the other two specimens fabricated. It is also observed that specimen 2 has a higher value of Ultimate Tensile Strength than specimen 1 and specimen 3 . From the microstructure analysis, it can be concluded that uniform distribution of reinforcement particles led to higher values of Ultimate Tensile Strength and Micro Vickers Hardness. The future research work based on this study can be based on the implementation of Machine Learning algorithms such as Artificial Neural Network, Support Vector Machines (SVM), and Decision Tree algorithm for the determination of the mechanical and microstructure properties as well as the geometrical properties analysis of the obtained microstructures by using an image processing algorithm.

\section{Acknowledgement}

The authors acknowledge the availability of open access papers in the domain of the fabrication of composites by casting process.

\section{References}

[1] Kumar S, Singh R, Hashmi MSJ. Metal matrix composite: a methodological review, Advances in Materials and Processing Technologies, 2020; 6:113 - 24. https://doi.org/10.1080/2374068X.2019.1682296

[2] Bahl S.Fiber reinforced metal matrix composites-a review, Materials Today: Proceedings 2020. https://doi.org/10.1016/j.matpr.2020.07.423

[3] Bhoi NK, Singh H, Pratap S. Developments in the aluminum metal matrix composites reinforced by micro/nano particles-a review, Journal of Composite Materials, 2020; 54:6 813 - 833. https://doi.org/10.1177/0021998319865307

[4] Güler Ö, Bağcı N. A short review on mechanical properties of graphene reinforced metal matrix composites, Journal of Materials Research and Technology, 2020; 9:3 6808 - 6833. https://doi.org/10.1016/j.jmrt.2020.01.077

[5] Węglewski W, Pitchai P, Bochenek K, Bolzon G, Konetschnik R, Sartory B, Ebner R, Kiener D, Basista M. Experimental and Numerical Investigation of the Deformation and Fracture Mode of Microcantilever Beams Made of $\mathrm{Cr}(\mathrm{Re}) / \mathrm{Al} 203$ Metal-Matrix Composite, Metallurgical and Materials Transactions A, 2020; 1 - 14. https://doi.org/10.1007/s11661-020-05687-3

[6] Ramesh P, Nataraj M. Automotive industry application of aluminium-based hybrid metal matrix composite, International Journal of Heavy Vehicle Systems, 2020; 27:1-2 18 - 32. https://doi.org/10.1504/IJHVS.2020.104412 
[7] Pandian V, Kannan S. Processing and preparation of aerospace-grade aluminium hybrid metal matrix composite in a modified stir casting furnace integrated with mechanical supersonic vibration squeeze infiltration method, Materials Today Communications, 2020; 101732. https://doi.org/10.1016/i.mtcomm.2020.101732

[8] Saleh BI, Ahmed MH. Development of functionally graded tubes based on pure $\mathrm{Al} / \mathrm{Al} 2$ 03 metal matrix composites manufactured by centrifugal casting for automotive applications, Metals and Materials International, 2020; 26:9 1430 - 1440. https://doi.org/10.1007/s12540-019-00391-3

[9] Singh H, Kumar D, Singh H, Development of magnesium-based hybrid metal matrix composite through in situ micro, nano reinforcements, Journal of Composite Materials, 2021; 55:1 109 - 123. https://doi.org/10.1177/0021998320946432

[10] Kumar A, Arafath MY, Gupta P, Kumar D, Hussain CM, Jamwal A. Microstructural and mechano-tribological behavior of $\mathrm{Al}$ reinforced $\mathrm{SiC}$-TiC hybrid metal matrix composite, Materials Today: Proceedings, 2020; 21: 1417 - 1420. https://doi.org/10.1016/j.matpr.2019.08.186

[11] Dinaharan I, Zhang S, Chen G, Shi Q. Development of titanium particulate reinforced AZ31 magnesium matrix composites via friction stir processing, Journal of Alloys and Compounds, 2020; 820: 153071. https://doi.org/10.1016/j.jallcom.2019.153071

[12] Say Y, Guler O, Dikici B. Carbon nanotube (CNT) reinforced magnesium matrix composites: The effect of CNT ratio on their mechanical properties and corrosion resistance, Materials Science and Engineering: A, 2020: 798; 139636. https://doi.org/10.1016/j.msea.2020.139636

[13] Chang, Z, Wu Y, Iizuka T, Peng L, Ding W. High-strength and high-modulus Al18B4033W/GWZ1031K magnesium matrix composite prepared by squeeze casting, Materials Science and Engineering: A, 2021: 817; 141393. https://doi.org/10.1016/i.msea.2021.141393

[14] Kumar NS. Fabrication and characterization of Al7075/RHA/Mica composite by squeeze casting, Materials Today: Proceedings, 2021: 37; 750 - 753 . https://doi.org/10.1016/j.matpr.2020.05.769

[15] Sekar K Mechanical and Tribological Properties of A7075/SiC/B4C Hybrid Composite fabricated by Stir and Squeeze Casting Method, In Key Engineering $\begin{array}{lllll}\text { Materials, } & 2021: & 882 ; & 77 & -\end{array}$ https://doi.org/10.4028/www.scientific.net/KEM.882.77 